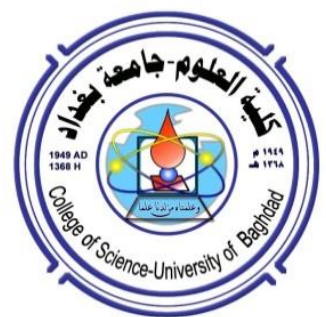

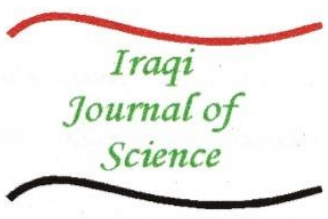

ISSN: 0067-2904

\title{
Structural, Optical and Morphological Characterization of Cdse/Cds Core / Shell Quantum Dots Synthesized via Chemical Bath
}

\author{
Mohammed Ali H Al-Beayaty $^{1^{*}}$, Lamiaa kh abbas ${ }^{2}$, Rana kadhim mohammed ${ }^{3}$ \\ ${ }^{I}$ College energy and environmental sciences, Al-karkh University of science, Baghdad, Iraq \\ ${ }^{2}$ Department of physics, college of science, University of Baghdad, Baghdad, Iraq \\ ${ }^{3}$ Department of biotechnology, college of science, University of Baghdad, Baghdad, Iraq
}

Received: 16/1/2021 Accepted: 30/6/2021

\begin{abstract}
$\mathrm{CdSe} / \mathrm{CdS}$ Core/shell nanostructures were prepared through the chemical synthesis method. XRD ,FESEM and TEM investigations confirmed the formation of core/shell structure for the sample. The AFM measurement was employed to reveal the morphology of the prepared thin films. Optical characterizations of the quantum dots were done by UV-visible and photoluminescence spectra. It was found that the quantum dots prepared has good optical properties. Due to the presence of shell coating on core $\mathrm{CdSe}$, the energy gap of the core/shell nanomaterial were increased from 2.2 to $2.3 \mathrm{eV}$. The resulted QDs are a promising candidate for photovoltaic and biosensor applications.
\end{abstract}

Keywords: nanoparticles, coreshell, cadmium selenide nanocrystals.

\section{الخصائص التركيبية, البصرية والمورفولوجيا لنقاط الكم لبنية قلب / قثرة CdSe/CdS المصنعة بواسطة التخليق الكيميائي}

\author{
محمل علي حسن غليم البياتي 1" , لمياء خضير عباس², رنا كاظم محلم3 \\ أقسم الطاقة المتجددة كلية علوم الطاقة والبيئة, جامعة الكرخ للعلوم , , بغداد, العراق. \\ 2ققسم الفيزياء , كلية العلوم, جامعة بغداد, بغداد, العراق. \\ 3قسم التقنيات الاحيائية , كلية العلوم, جامعة بغداد, بغداد , العراق. بغاد.

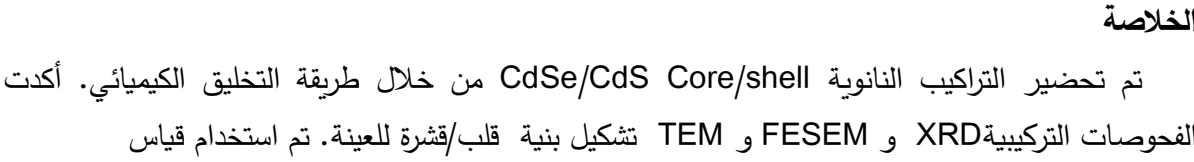 \\ للكثف عن مورفولوجيا الأغشية الرقيقة المحضرة. تم إجراء فحوصات الخواص البصرية للنقاط الكمومية

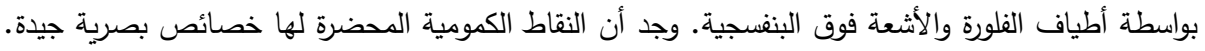

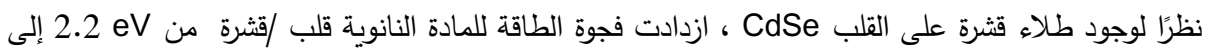 \\ CdSe / CdS للتراكيب النانوية ـ النتيجة CdSe / CdS 2.3 eV

$$
\text { هي مرشح واعد للتطبيقات الكهروضوئية و الاستشعار الحيوية. }
$$

\section{Introduction}

II-VI Semiconductors are nanoparticles that are used in many physical applications. It has a wide and direct band gap, so it is used in many applications such as optoelectronics and

\footnotetext{
*Email: Albeaty33@kus.edu.iq
} 
nonlinear optics [1].

Nanoparticle substances are used in experimental and theoretical studies because they have many properties that are of importance in many technological applications [2] such as Quantum dots [3], probes of the genetic material [4], fluorescence probes [5].

Quantum dots are used in different fields such as solar cells $[6,7,8]$, Photo catalysis $[9,10]$, Light-emitting devices [11], Optical amplifiers [12], and Biomedical imaging applications [13].

CdSe quantum dots are quantum dots that are used as biomarkers in experimental fields in medicine and biology because they have luminescence properties and could

cover all visible wavelength so they are very important for visualizing tissues and cells [14].

Salem et al. synthesized CdSe NPs by the heat treatment method at different temperatures (450-700) ${ }^{\circ} \mathrm{C}$ in $\mathrm{O}_{2}$ and $\mathrm{N}_{2}$ environment. Selenium powder was dissolved in ethylenediamine by heating at $\left(200^{\circ} \mathrm{C}\right)$ for two hours then adding the cadmium nitrate and metal precursor then polyvinylpyrrolidone. Many tests and measurements were done to analyze ingof the structure [15].

In 2014, Ramanery et al. synthesized $\mathrm{CdSe} / \mathrm{CdS}$ stabilized by polymer ligand using aqueous colloidal solution at $\left(25^{\circ} \mathrm{C}\right)$. UV-Vis spectroscopy, photoluminescent (PL) spectroscopy, and transmission electron microscopy (TEM) were employed to characterize the CdSe quantum dots [16].

Hao et al. described the optical and structural characterization (using UV-Vis, PL, XPS, XRD, and HRTEM) of CdSe and CdSe/CdS NPs produced by the micro emulsion method then refluxing in toluene/methanol (60:1) [17].

In 2019, Gadalla et al. described an effective modified organometallic precursors method for producing a composite of quantum dots consisting of CdSe (core) with CdS (shell). The sizes of the nanoparticles were estimated from XRD CdSe/CdS $3.64 \mathrm{~nm}$ and compared with HRTEM $3.75 \mathrm{~nm}$ with shell thickness $0.6 \mathrm{~nm}$. and optical spectra. UV-Vis spectroscopy showed a systematic red shift in the absorption and emission spectra after the deposition of CdS which confirms the shell growth over the CdSe core [18].

In this study, the effect of CdS shell deposited on the CdSe core was investigated by characterizing the structural, morphological and optical properties of $\mathrm{CdSe}$ and $\mathrm{CdSe} / \mathrm{CdS}$ QDs which were fabricated using the chemical reaction method.

\section{Experiment Setup}

Cadmium chloride $\left(\mathrm{CdCl}_{2}\right)$ of $99.9 \%$ purity, sodium sulfide $\left(\mathrm{Na}_{2} \mathrm{SO}_{3}\right)$ (99.9\% purity), Selenium (Se), $\mathrm{Na}_{2} \mathrm{~S}$, and natural Gelatin with high molecular weight were all provided from Sigma Aldrich Company, without any further purification.

Cadmium Selenide (CdSe) NPs were prepared as colloid from the reaction of $\mathrm{CdCl}_{2}$ (solution 1) and $\mathrm{Na} 2 \mathrm{SeSO} 3$ (solution 2) with 2:1 volume ratios where the two solutions containing $0.02 \mathrm{M}$ of $\mathrm{Se}$ ions and $0.04 \mathrm{M}$ of $\mathrm{Cd}$ ions with gelatin .Mixing of the two solutions together in a three-neck flask, where the first solution which gives the $\mathrm{Cd}$ ions is placed in the flask (was prepared at $50^{\circ} \mathrm{C}$ for $30 \mathrm{~min}$ ) then the second solution of Se ions was poured on it (was prepared at $80^{\circ} \mathrm{C}$ for $3 \mathrm{~h}$ ), and finally, ammonium hydroxide was added to the mixture at room temperature to adjust the $\mathrm{pH}$ of the solution to the required level( $\mathrm{pH}=7.2-7.4)$ with flowing argon gas for a half-hour until production of the CdSe-NPs (as shown in Figure 1. 


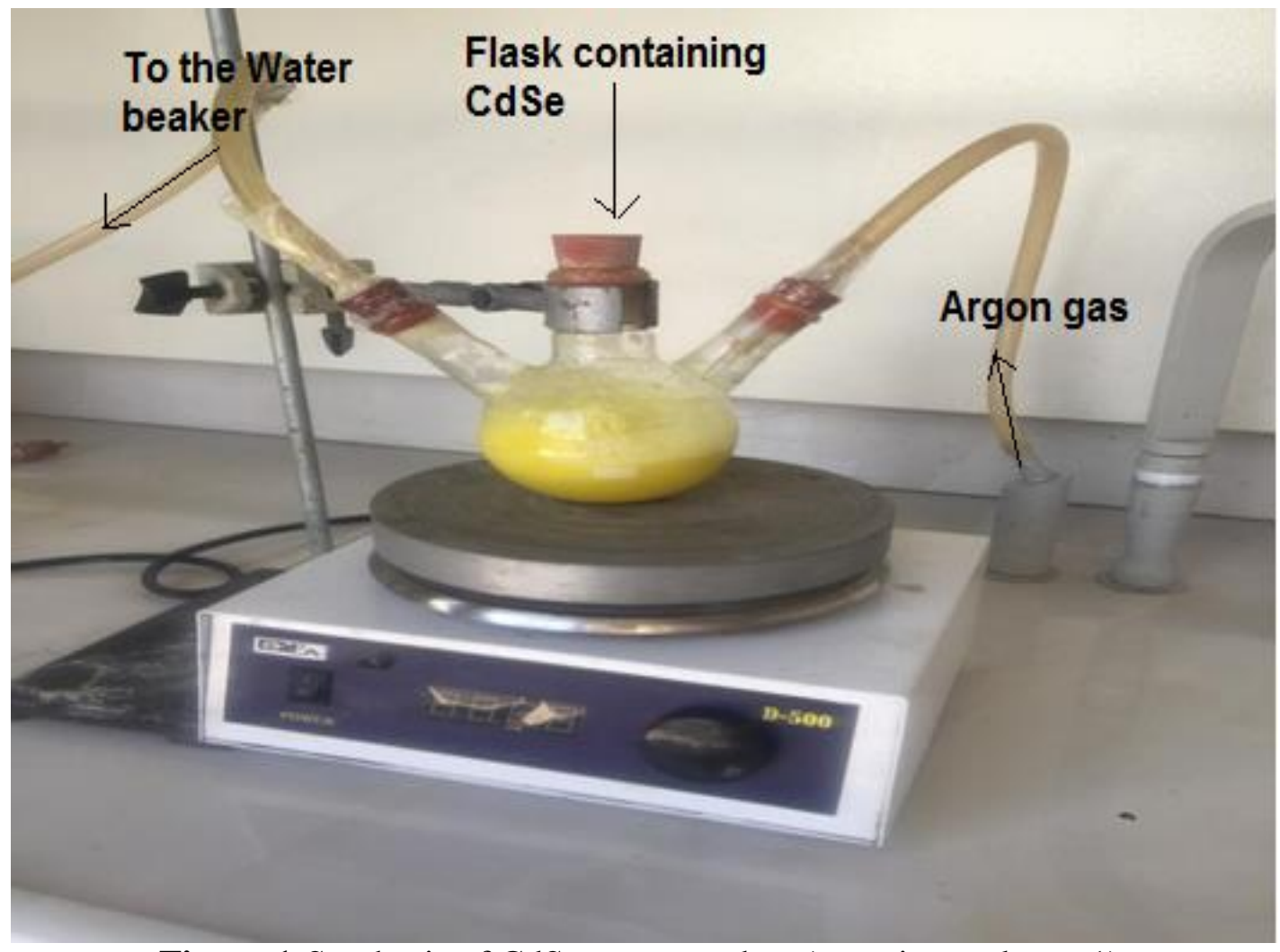

Figure 1-Synthesis of CdSe quantum dots (experimental step 1).

The reaction for the formation of core/shell CdSe/ CdS QDs was done in two threenecked flasks (as shown Figure 2. ( $\left.\mathrm{F}_{1}\right)$ flask contains $\mathrm{Na}_{2} \mathrm{~S}$ solution. A syringe containing sulfuric acid $\left(\mathrm{H}_{2} \mathrm{SO}_{4}\right)(98 \%)$ was fitted to the second opening of $\mathrm{F}_{1}$. The other two openings were for argon gas supply and for connection to the second flask(F2). The second flask contains $\mathrm{CdSe}$ quantum dots $(150 \mathrm{ml}) . \mathrm{H}_{2} \mathrm{~S}$ gas, the resultant of the reaction of $\mathrm{Na}_{2} \mathrm{~S}$ with $\mathrm{H}_{2} \mathrm{SO}_{4}$, from $\mathrm{F} 1$ passes through to the second flask. The third opening of $\mathrm{F} 2$ provides gas outlet. The end of the outlet tube was put in an external beaker filled with $\mathrm{NaOH}$ in order to collect any unreacted gas.

$\mathrm{O}_{2}$ must first be removed from $\mathrm{F} 1$ and $\mathrm{F} 2$ and this was done by the continuous pumping of argon gas for several minutes. Sulfuric acid was injected dropwise via the syringe into the first flask. The resultant $\mathrm{H}_{2} \mathrm{~S}$ gas passes through to the second flask with argon gas flow. Bubbles formed by the argon gas in the second flask will agitate the CdSe solution thus $\mathrm{H}_{2} \mathrm{~S}$ would react with $\mathrm{Cd}^{+2}$ to cap the CdSe QDs. The quantity of $\mathrm{H}_{2} \mathrm{~S}$ provided to the second flask was regulated by the number of $\mathrm{H}_{2} \mathrm{SO}_{4}$ drops added into the first flask ( the final reaction event was carried out at room temperature). The method adapted in this work was that of $\mathrm{Xu}[14]$. 


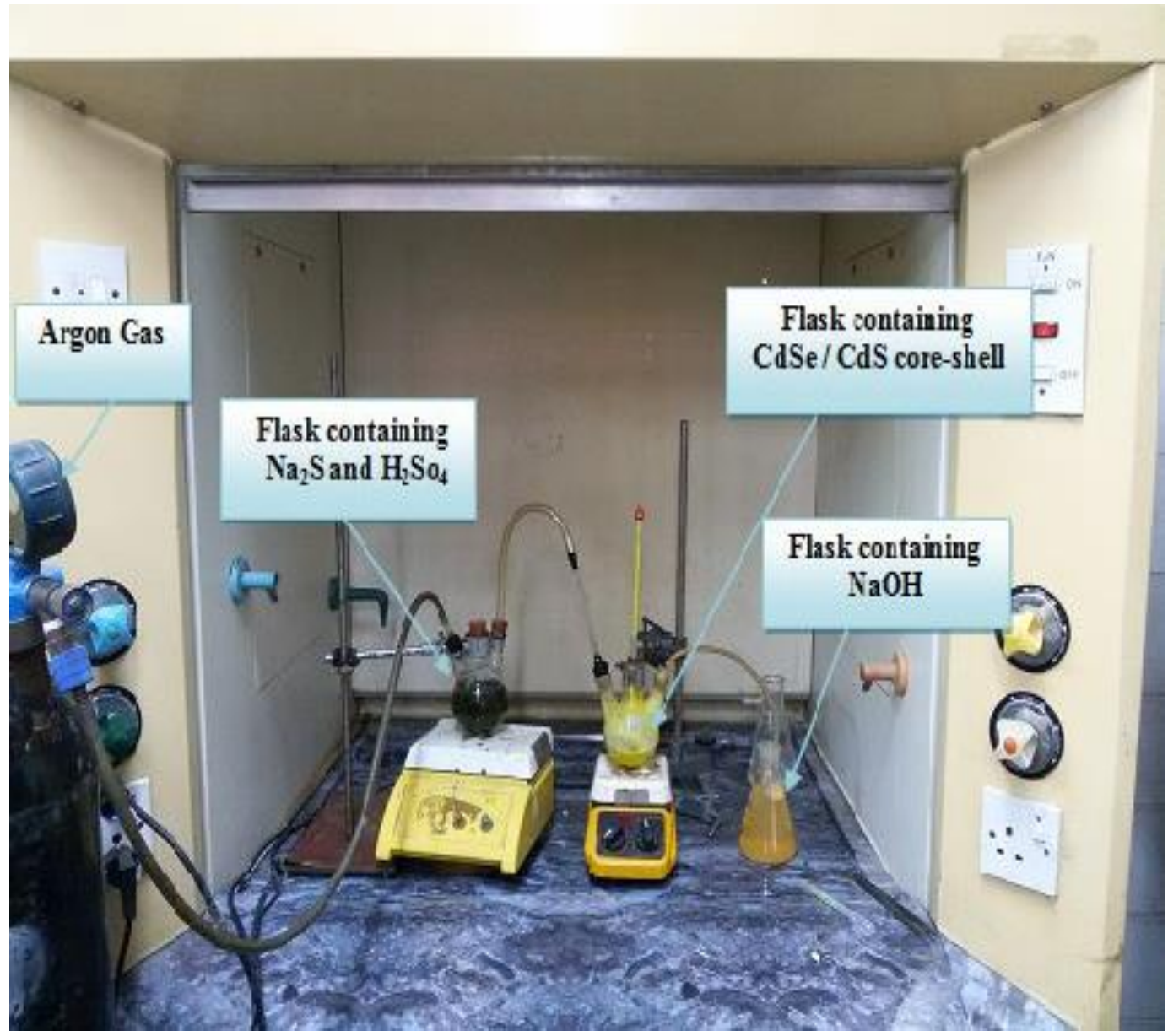

Figure 2-Synthesis of CdSe /CdS quantum dots (experimental step 2).

\section{Results and dissections}

Figure 3 shows the XRD patterns of CdSe nanoparticles and CdSe/CdS core/shell quantum dots prepared by the chemical bath method. The CdSe pattern shows broad peaks that appeared at $2 \theta=25.55^{\circ}, 29.21^{\circ}, 42.54^{\circ}$, and $49.95^{\circ}$ assigned to (111), (200), (220), and (311) lattice planes, respectively. For cubic zinc blend the CdSe structure was identical with the standard card (JCPDS-65-2891). The CdSe/CdS QDs exhibit the same structure of CdSe QDs with (111) and (220) planes located at $2 \theta=25.05^{\circ}$ and $43.08^{\circ}$, respectively, with decrease of crystallinity which is indicated by the more broadening in the preferred peak (111) with small shift towards the lower angle. This similarity in structure of the CdSe (NPs) and the $\mathrm{CdSe} / \mathrm{CdS}$ core/shell particles ensures the formation of core/shell. This result is similar to that of the $\mathrm{CdSe} / \mathrm{CdS}$ and $\mathrm{CdS} / \mathrm{ZnS}$ nanocrystals prepared by Hines and Guyot-Sionnest using the epitaxial encasing method [19]. 


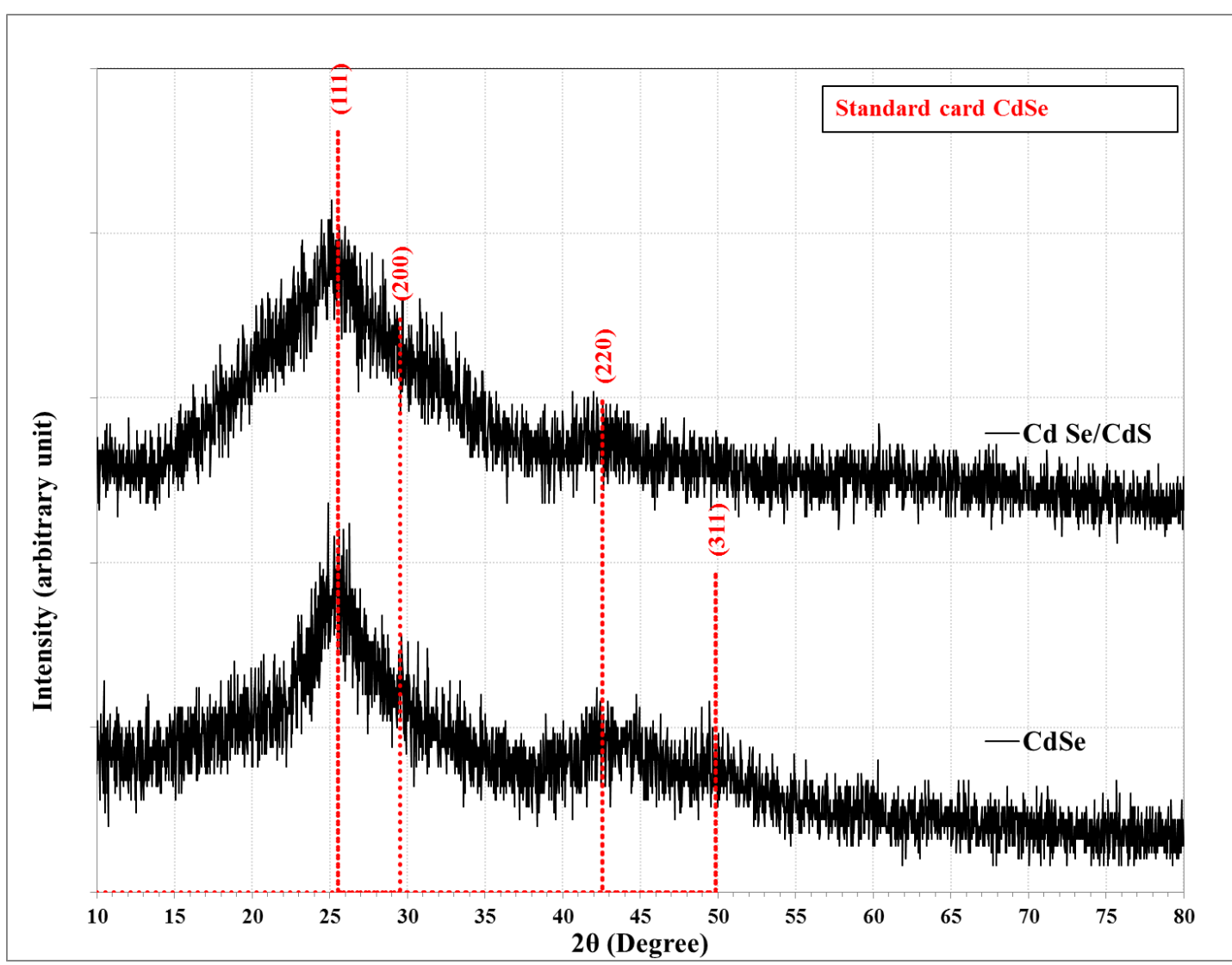

Figure 3-X-ray diffraction patterns of $\mathrm{CdSe}$ and $\mathrm{CdSe} / \mathrm{CdS}$ nanoparticles powders .

Table 1- X-ray powder diffraction patterns parameters of CdSe and CdSe/CdS nanoparticles.

\begin{tabular}{c|ccccc}
\hline Sample & $2 \theta$ (Deg.) & FWHM (Deg.) & $\mathrm{d}_{\mathrm{hkl}}$ Exp. $(\AA)$ & $\mathrm{hkl}$ & Phase \\
\hline \multirow{2}{*}{$\mathrm{CdSe}$} & 25.5591 & 3.9293 & 3.4824 & $(111)$ & $\mathrm{CdSe}$ \\
& 42.5441 & 1.2675 & 2.1232 & $(220)$ & $\mathrm{CdSe}$ \\
& 49.9593 & 1.4259 & 1.8241 & $(311)$ & $\mathrm{CdSe}$ \\
$\mathrm{CdSe} / \mathrm{CdS}$ & 25.0521 & 4.3730 & 3.5517 & $(111)$ & $\mathrm{CdSe}$ \\
& 43.0828 & 2.8203 & 2.0979 & $(220)$ & $\mathrm{CdSe}$ \\
\hline
\end{tabular}

The FESEM images of the synthesized CdSe and CdSe/CdS nanoparticles are shown in Figure 4( $\mathrm{a}$ and b). It is noted that $\mathrm{CdSe} / \mathrm{CdS}$ and CdSe have spherical granules of nearly equal size, all of which are less than ten nanometers. This confirms the formation of the quantum dots and the capping process for CdSe by CdS [20,21 ,22] and the surface of samples become smoother [23].



Figure 4: FESEM image of the synthesized a- CdSe and b- CdSe/CdS nanoparticles. 
Figure 5 shows the 2D and 3D AFM images of CdSe/CdS core/shell QDs thin film. The 2D image shows a homogenous roughness and a uniform film with no voids, while the 3D image shows equal sized granules in the whole area of the thin film. This result supports the result obtained by FESEM.

The AFM measurements gave information about the (RMS) roughness and average grain size which were $13.039 \mathrm{~nm}$ and $17.556 \mathrm{~nm}$, respectively.[24]

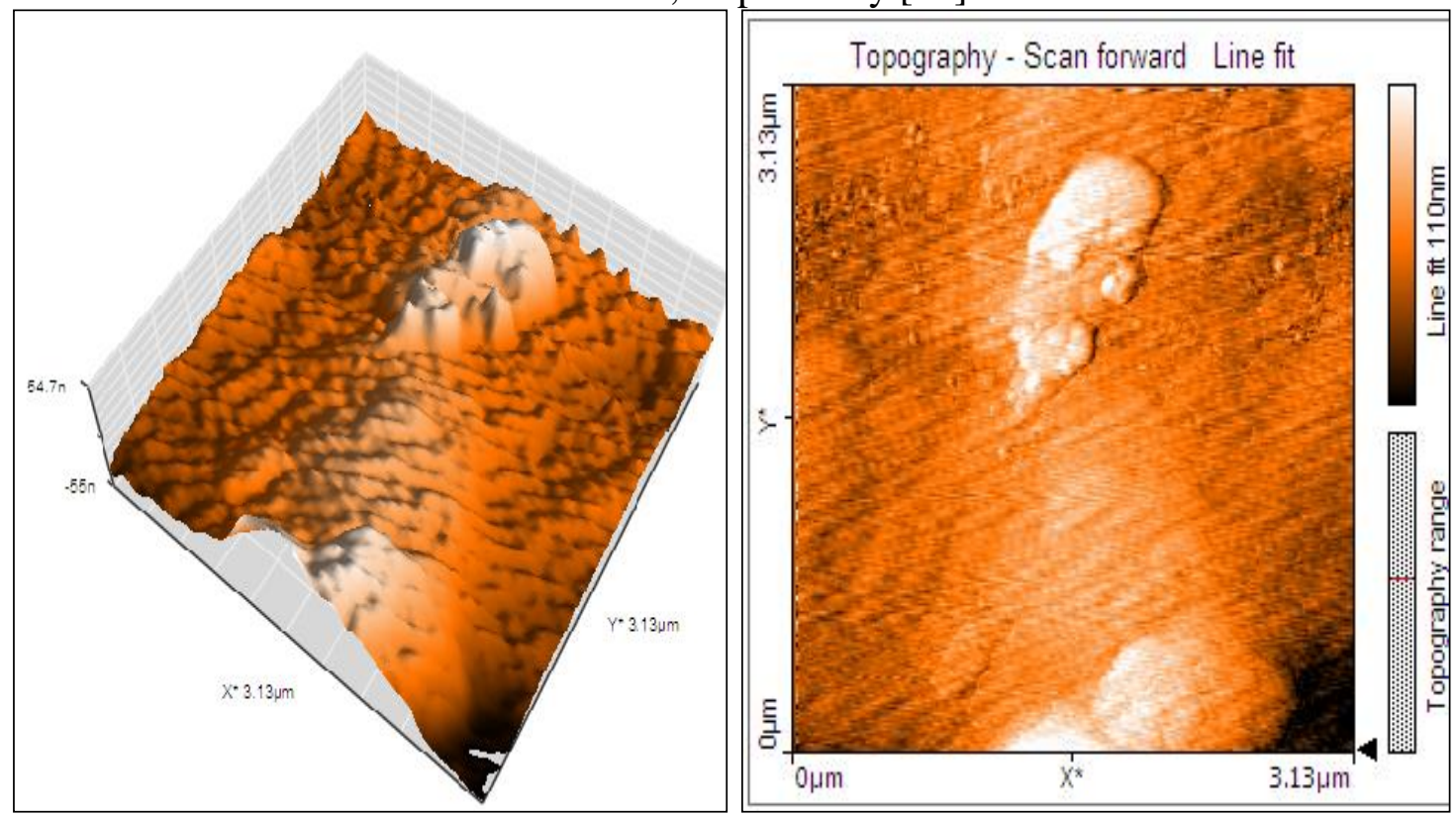

Figure 5-2D and 3D AFM images of CdSe/CdS.

The TEM images of CdSe/CdS core/shell QDs are shown in Figure 6. It is observed from the first figure the presence of mono-dispersed sphere shaped nanoparticles and the high density of $\mathrm{CdSe} / \mathrm{CdS}$ QDs. The size of $\mathrm{CdSe} / \mathrm{CdS}$ Core/shell QD, from the second figure, was measured to be less than $5 \mathrm{~nm}$. The prepared particle diameter $(5 \mathrm{~nm})$ is consistent with the reported core/shell structure model for the CdSe/CdS sample [25]. This result is in agreement with that of Gadalla et al.[18] . It can also be seen that the black points represent the core, while the shadows around the core may be attributed to the shell formed around the core.

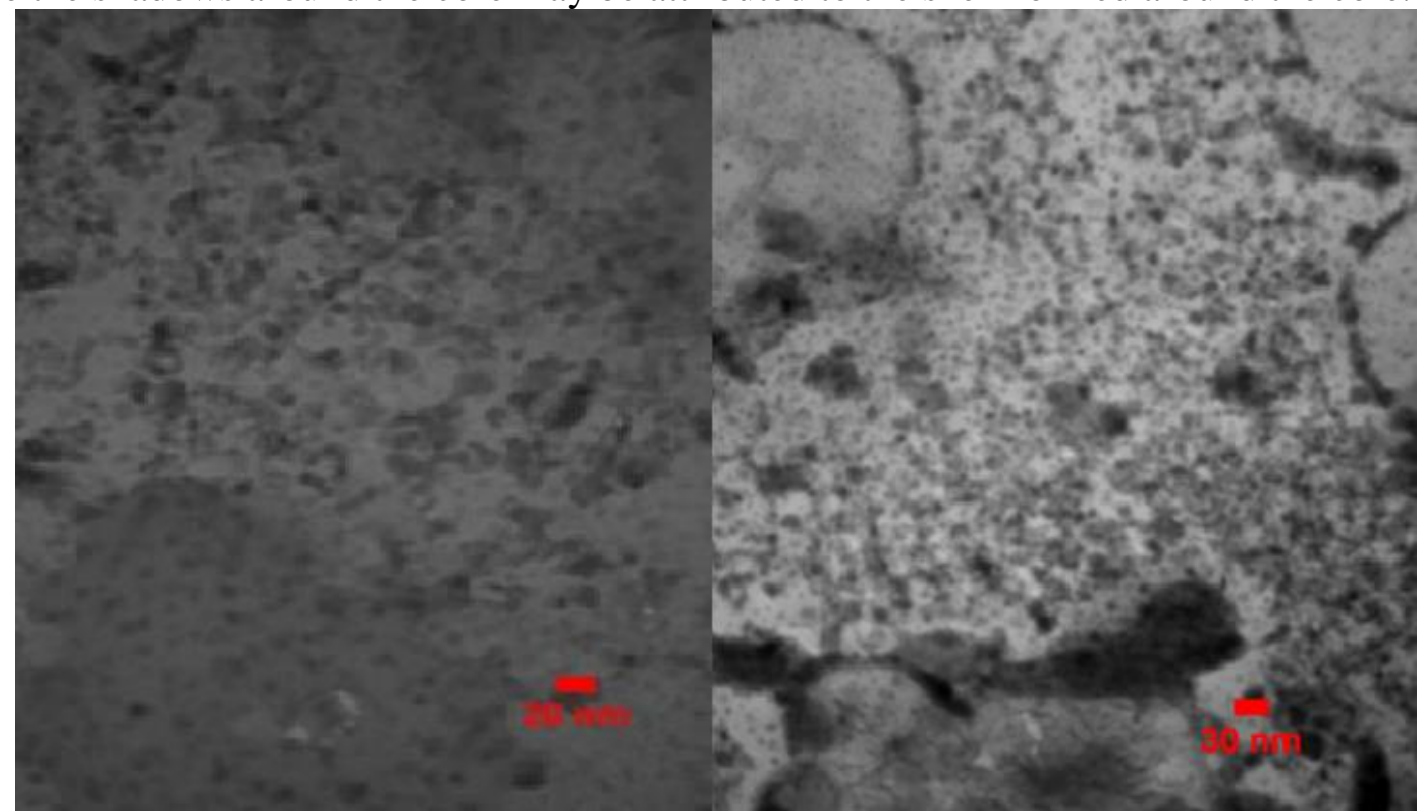

Figures 6-TEM images for CdSe/CdS core / shell. 
The comparison between the energy gaps of the CdSe and CdSe/CdS QDs are shown in Figure 7 ( $a$ and $b$ ). The absorption edge shifted towards a lower wavelength value for $\mathrm{CdSe} / \mathrm{CdS}$ core/shell QDs compared with that of the CdSe nanoparticles.

The energy gaps for the two samples were calculated using Tauc formula as illustrated in Figure 7. The increase in the energy gap from $2.2 \mathrm{eV}$ for $\mathrm{CdSe}$ to $2.3 \mathrm{eV}$ for $\mathrm{CdSe} / \mathrm{CdS}$ QDs can be noticed. The diameter of the CdSe QDs depends on the energy of UV-Vis. according to the following equation:

$$
E_{g(Q D)}=E_{(\text {bulk })}+h^{2} / 8 R^{2}\left(1 / m_{e^{*}}+1 / m_{h^{*}}\right)
$$

Where $\mathrm{E}_{\mathrm{g}(\mathrm{QD})}$ is QDs band gap energy, $\mathrm{E}_{(\text {bulk })}$ is band gap energy of bulk $\mathrm{CdSe}(1.74 \mathrm{eV}), \mathrm{m}_{\mathrm{e}}$ * is the effective mass of electron $\left(1.18 \times 10^{-31}\right), \mathrm{m}_{\mathrm{h}} *$ is the effective mass of hole $\left(4.09 \times 10^{-31}\right), \mathrm{h}$ is the Planck's constant and $\mathrm{R}$ is the radius of QDs.

The CdSe QDs radius was $(2.61 \mathrm{~nm})(5.22 \mathrm{~nm}$ diameter), while the CdSe/CdS QDs diameter was $(6.636 \mathrm{~nm})$. The QDs diameter was greater than that obtained from the XRD . QDs were spherical based on the Brus model. The quantum confinement energy of the CdSe QDs was obtained from $\mathrm{E}_{\mathrm{g}(\mathrm{qd}) \_} \mathrm{E}_{\mathrm{bulk}}$ which were equal to $0.46 \mathrm{eV}$ and $0.56 \mathrm{Ev}$, respectively [25].

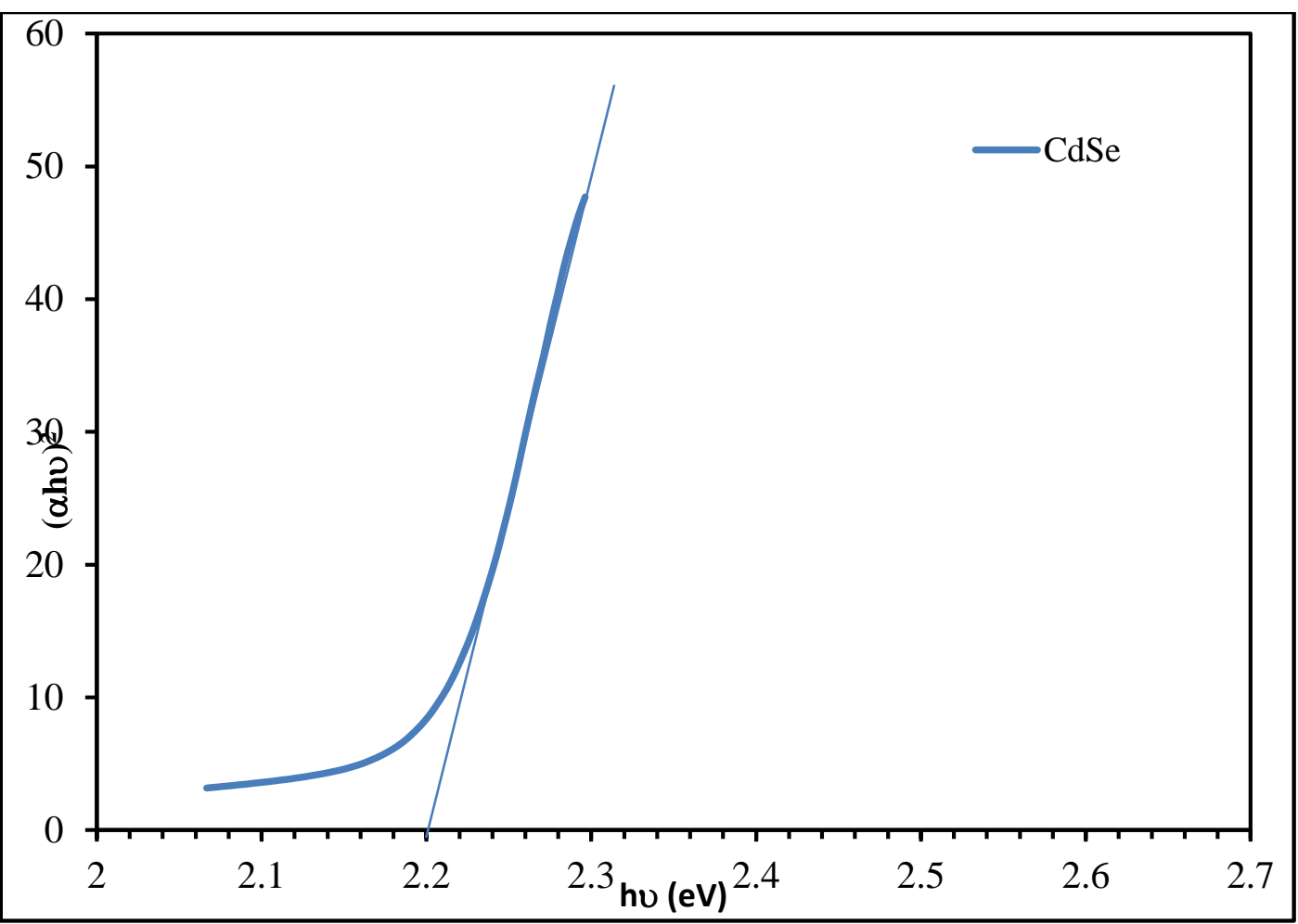

Figure 7(a)-Tauc relation used to calculate the CdSe QDs energy gap. 


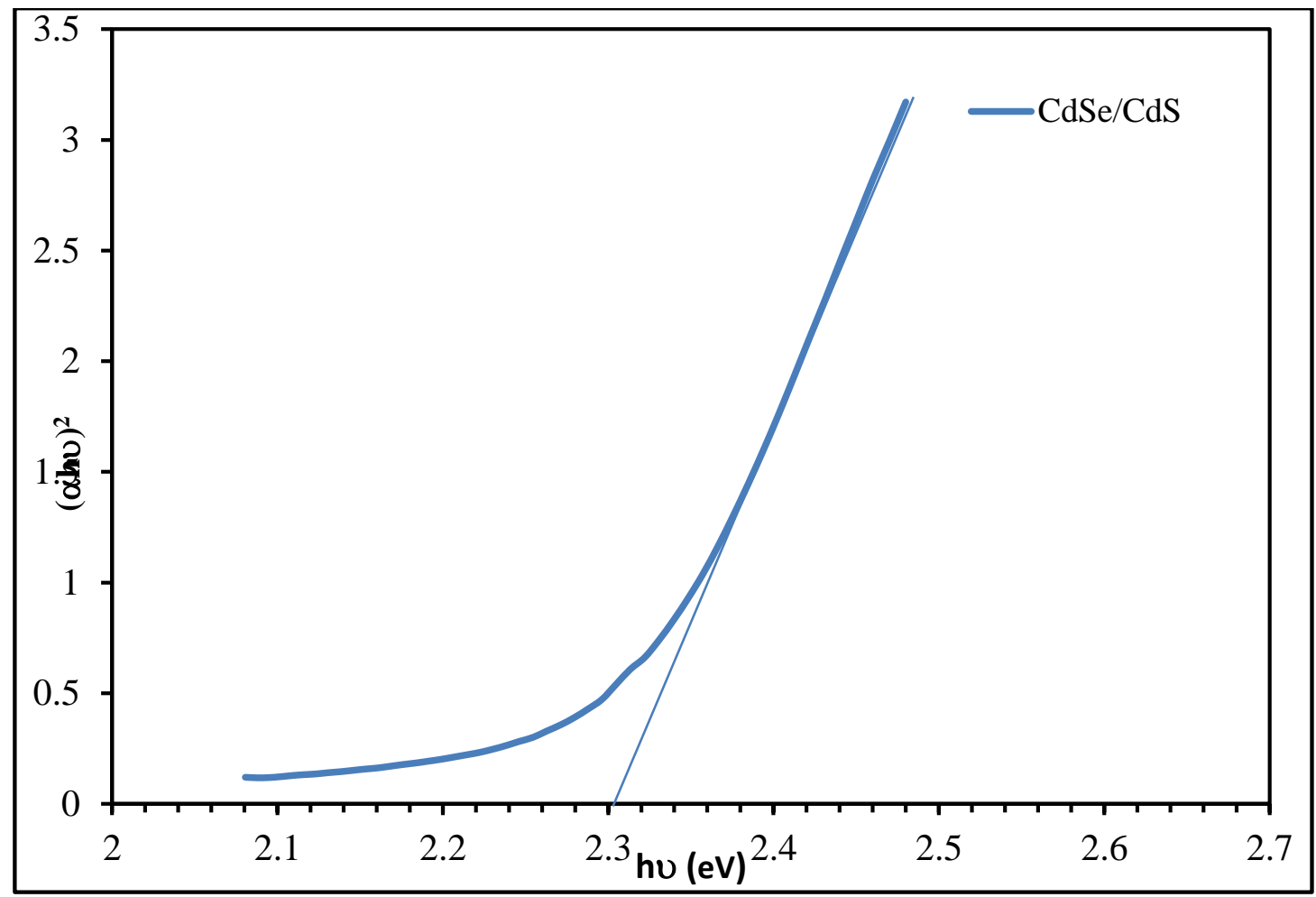

Figure 7(b)-Tauc relation used to calculate the CdSe/CdS QDs energy gap.

Recording of the fluorescence spectra was done by stimulation of the wavelength $(350 \mathrm{~nm})$. The $\mathrm{CdSe}$ and $\mathrm{CdSe} / \mathrm{CdS}$ core/shell QDs fluorescence spectra are shown in Figure 8. $\mathrm{CdSe} / \mathrm{CdS}$ QDs spectrum revealed well-resolved emission maxima at $(624 \mathrm{~nm})$ while that of CdSe QDs was recorded at (640nm) . When the accumulation of the CdS shell on CdSe QDs, a blue shift of fluorescence peak occur. CdSe/CdS core/-shell QDs have high fluorescence when compared with CdSe QDs.

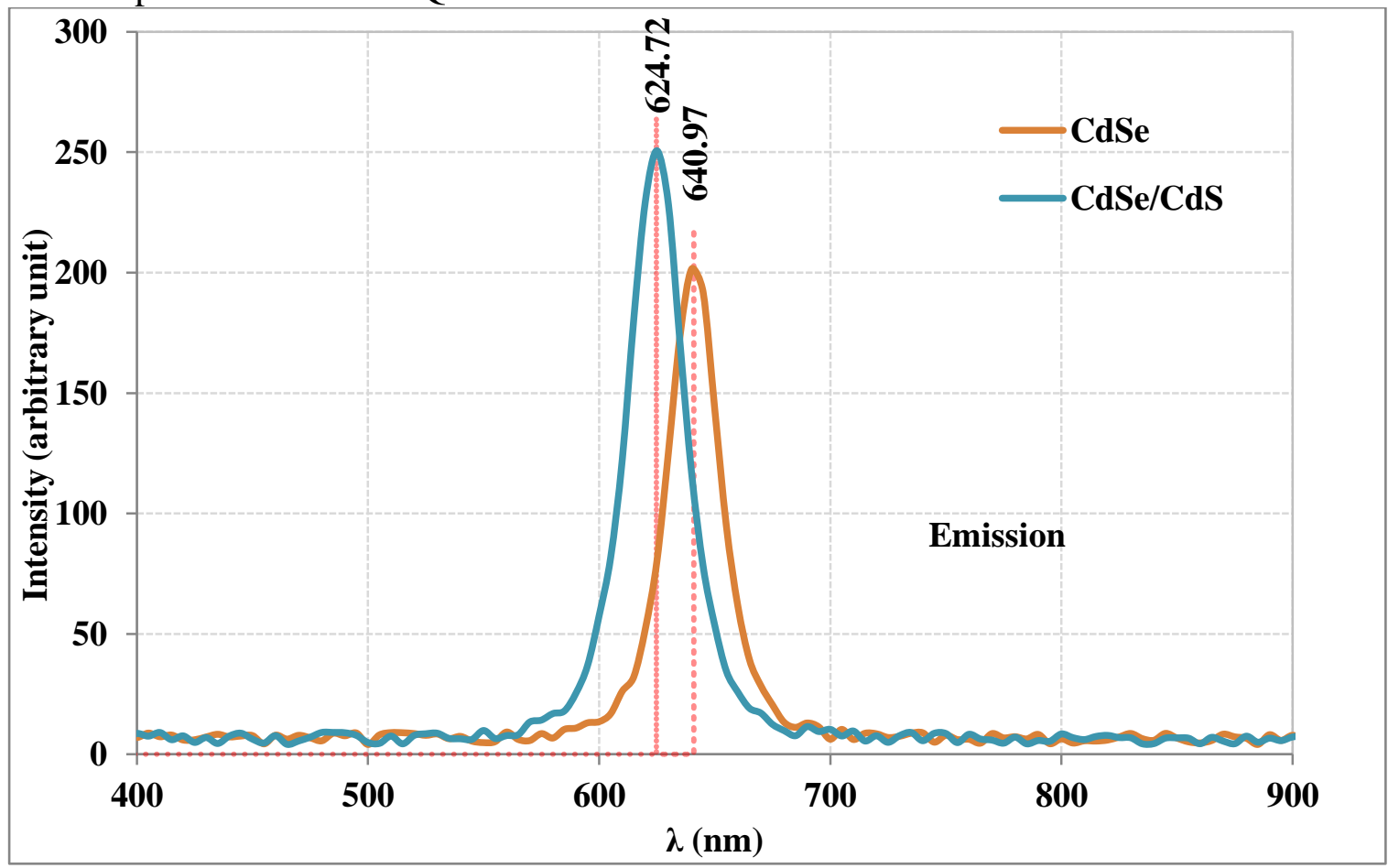

Figure 8-CdSe \& CdSe/CdS core-shell QDs Fluorescence spectra. 


\section{Conclusions}

$\mathrm{CdSe} / \mathrm{CdS}$ Core/shell nanostructure was prepared by the chemical synthesis method. The XRD investigation showed a decrease of crystallinity with small shift towards the larger angles and ensured the formation of core/shell. The TEM measurements confirmed the formation of core/shell structure for the sample. The AFM image showed homogenous roughness and a uniform film with no voids. Due to the presence of CdS shell coating the CdSe core, the energy gap of the $\mathrm{CdSe} / \mathrm{CdS}$ core/shell has increased from 2.2 to $2.3 \mathrm{eV}$ which confirmed the formation of core/shell structure. The results obtained make QDs a promising candidate for photovoltaic and biosensor applications.

\section{References}

[1] G. A. Martínez-Castañón, J. P. Loyola-Rodríguez, J. F. Reyes-Macías, N. NiñoMartínez, Facundo Ruiz, "Synthesis and optical properties of functionalized CdS nanoparticles with different sizes," Superf. Y Vacio., Vol. 23, No. 4, pp. 1-4, 2010.

[2] R. Prabhu and M. Abdul Khadar, "Characterization of chemically synthesized CdS nanoparticles," Pramana J. Phys., Vol.56, , pp. 801-807, 2005.

[3] P.P. Favero, M. de Souza-Parise, J.L.R.Fernandez, R. Miotto and A. C. Ferraz, "Surface properties of CdS nanoparticles," Braz. J. of Phys., Vol.36, No. 3b, pp. 1032-1034, 2006.

[4] K. Manickathai, M. Alagar, S. Kasi Viswanathan, "Synthesis and Characterization of CdO and CdS nanoparticles," Ind J. Pure Ap. Phy. Vol. 46, No 8, 561-564, 2008.

[5] U. Pal, G. Loaiza, A. Bautista Hernández, O. Vázquez Cuchillo, " Synthesis of CdS nanoparticles through colloidal rout," Superf. Y Vacio., Vol.11, pp 40-43, 2000.

[6] R. R. Lunt, T. P. Osedach, , P. R. Brown, J. A. Rowehl and V. Bulovic , "Practical roadmap and limits to nanostructured photovoltaics," Adv. Mater., Vol. 23, No.48, pp.5712-5727, 2011.

[7] P. V. Kamat, "Boosting the efficiency of quantum dot sensitized solar cells through modulation of interfacial charge transfer," Acc Chem. Res., Vol.45, No. 11, pp.1906-1915, 2012.

[8] K. Suranaa, I. T. Salisua, R .M. Mehra and B. A. Bhattacharya," simple synthesis route of low temperature CdSe-CdS core-shell quantum dots and its application in solar cell," Opt Mater., Vol.82, pp.135-140, 2018.

[9] W. Fan, Q. Zhang, and Y.Wang, "Semiconductor-based nanocomposites for photocatalytic H2 production and $\mathrm{CO}_{2}$ conversion," Phys Chem. Chem. Phys., Vol. 15, No.8, pp.2632-2649, 2013.

[10] O'Connor T, Panov MS, Mereshchenko A, Tarnovsky AN, Lorek R, Perera D, Diederich G, Lambright S, Moroz P, Zamkov, " The effect of the charge-separating interface on exciton dynamics in photocatalytic colloidal heteronanocrystals," ACS Nano., Vol.6, No.9, pp. 81568165.

[11] Y. Shirasaki, G. J. Supran, M. G. Bawendi, V. Bulovic, " Emergence of colloidal quantum-dot light-emitting technologies," Nat. Photonics., Vol.7, pp.13-23, 2013.

[12] B .Dieter, W.P Udo," Quantum dots: promises and accomplishments," Mater. soday., vol.14 No.9, pp.388-397, 2011.

[13] T. L. Doane and C. Burda, " The unique role of nanoparticles in nanomedicine: Imaging, Drug," Chem Soc Rev., Vol. 41(7), pp. 2885-2911, 2012.

[14] Y. Xu ,"Synthesis and Characterization of Silica Coated CdSe/CdS Core/ Shell Quantum Dots," Ph.D. thesis Virginia Polytechnic, Institute and State University., 2005.

[15] A.Salem, E. Saio,N.M. Al-Hada, H. M. Kamari, A. H.Shaari, C. Azurahanim, C. Abdullah, S. Radiman "Synthesis and characterization of CdSe nanoparticles via thermal treatment technique," Results Phys., Vol. 7, pp.1556-1562, 2017.

[16] F. P. Ramanery, A. A. P. Mansur and H. S. Mansur," Synthesis and characterization of waterdispersed $\mathrm{CdSe} / \mathrm{CdS}$ core-shell quantum dots prepared via layer-by-layer method capped with carboxylic-functionalized poly(vinyl alcohol," Mater Res., Vol.17,Suppl 1, pp. 133-140, 2014.

[17] E.i Hao,H. Sun, Z. Zhou, J. Liu, B.Yang, and J. Shen " Synthesis and optical properties of CdSe and CdSe/CdS nanoparticles ," Che Mater., Vol. 11, No. 11, pp. 3096-3102, 1999.

[18] R.H.A. Gadalla, M. Abd el-sadek, R. Hamood "Synthesis and optical properties of CdSe/CdS core/shell nanocrystals," Mater Sci., Vol.37, No.2, pp.149-157, 2019.

[19] M.A. Hines and P. Guyot-Sionnest," Synthesis and characterization of strongly luminescing ZnS- 
capped CdSe nanocrystals," J Phys Chem., Vol. 100 , No.2, pp.468-471, 1996.

[20] P. Kluson, M. Drobek, H. Bartkova, I. Budil, "Welcome in the Nano world," Chem.Listy ., Vol. 101, pp. 262-272, 2007.

[21] A. Ferancova, J. Labuda, "DNA Biosensors based on nanostrucutred materials," In: Eftekhari A (Editor),DNA Biosensors Based on Nanostructured Materials. Chapter 11Wiley-VCH;

[22] Weinheim, Nanostrucutred Materials in Electrochemistry., Germany, pp. 409-434, 2008.

[23] V. Kral, J. Sotola, P. Neuwirth, Z. Kejik, K. Zaruba, P. Martasek, "Nanomedicine - Current status and perspectives: A big potential or just a catchword," Chem. Listy., Vol. 100,No. 1, pp. 4-9, 2006.

[24] M.V.Haritha, C.V.V.M. Gopi, C.V.Thulasi-Varma, S. K. Kim and H. J. Kim, " Influence of $\mathrm{Mn}^{+2}$ incorporation in CdSe quantum dots for high performance of CdS-CdSe quantum dot sensitized solar cells," J Photochem Photobio A: Chem., Vol. 315, pp. 34-41, 2016.

[25] S. Reghuram, A. Arivarasan, R. Kalpana and R. Jayavel, " CdSe and CdSe/ZnS quantum dots for the detection of C-reactive protein," J. Exp Nanosci., Vol. 10, No. 10, pp.787-802, 2015. 